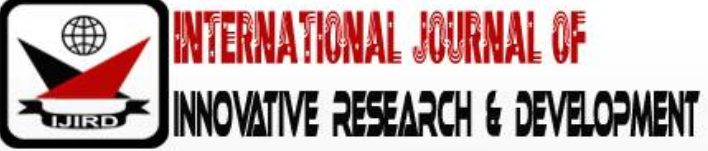

ISSN 2278 - 0211 (Online)

\section{Moral Reasoning and Cheating in Examination among Secondary Students in Ghana}

\author{
Alexander Kyei Edwards \\ Senior Research Fellow, Department of Institute for Educational Research and Innovations Studies, \\ University of Education, Ghana \\ Sarah Entsuah \\ Senior Assistant Registrar, Department of Centre for Languages and Liberal Studies, \\ Takoradi Technical University, Ghana
}

\begin{abstract}
:
The study intended to investigate the moral reasoning behind secondary students cheating at examinations in selected secondary schools within one school district in Ghana. The research design is descriptive survey. A sample of 420 was selected by simple random sampling method from three Senior High schools (SHS). Data came from a questionnaire with a demographic information section and a moral scenario on cheating at examination with 16 items on different Likert scales. With that moral scenario, judgment mean scores, moral reasoning simple sum scores, P-scores, are all calculated and aggregated to give levels of moral reasoning. The levels of moral reasoning are further analysed along with pre-examination confidence level (PECL) scores to answer both a research question and test of a hypothesis. Results show majority of the students' developing a normality in moral reasoning at the Kohlberg's stage 3 and 4 (Conventional stages). PECL data shows tendencies of aligning behaviours to opportunity available to help. Recommendations include practical measures by education providers to educate students on risks and consequences of cheating, stake holders advocacy on examination malpractices, and policy direction leadership to give significant attention to cheating at examination in secondary schools in Ghana.
\end{abstract}

Keywords: Examination cheating, Ghana education, moral reasoning, secondary school students, SHS

\section{Introduction}

In discussing moral reasoning James Rachels explained that it must be divorce of personal feelings, "When we feel strongly about an issue, it is tempting to assume that we just know what the truth must be, without even having to consider the arguments on the other side" (Rachels \& Rachels, 2007a, p. 11). Moral reasoning has so many factors influencing its measure that it can best be explained as; “a person's moral judgment characterized by his or her judgment, [based on] socio-moral understanding, and interpretation of moral dilemmas" (Edwards, 2009, p. 19). Moral reasoning is indicative of the level of recognition of moral judgment and capacity to provide a moral-problem-solution. The moral reason for doing something 'right' or 'wrong' may be due to choice availability, which may also be engineered by developmental determinants such as socio-cultural practices, traditional norms, societal interpretations, plus cultural philosophies (Rachels \& Rachels, 2007b).

Philosophically, moral development has been discussed along the lines of how people reason when confronted with a moral dilemma (Kohlberg, 1985; Rest 1984). Classical moral development studies since Jean Piaget and Lawrence Kohlberg era have assumed measurement surrounding the cognitive processes (as cited in Passini, 2014). Stefano Passini (2014) recognizes other new approaches to moral development that suggest that it is not only cognitive domain that affect moral reasoning, but "emotions and insights may instead affect many of our moral judgments" (p. 89). Moral reasoning has everything to do with moral development (Rest, 1986). At a certain level in human development a person may exercise judgment based on their level of moral development and hence reasoning. Sometimes these behaviours are prompted by opportunity.

The issue of students cheating during examination under discussion is critical. Almost every examination conducted by the West African Examination Council (WAEC) have had issues with students cheating. It has become acceptable to see a media release of provisional results due to investigations. In 2017 a total of 117,306 candidates who sat for the WASSCE for 2017 private candidates had results investigated (Ghanaweb, 2017). In another instance, "the results of 1,873 candidates, alleged to have been involved in various examination malpractices, have been withheld pending the conclusion of investigations into the cases" (Ghanaweb, 2018, Article on cheating).

In 2014 the Brong Ahafo region was ranked top when it comes to cheating in examinations. Obviously, authorities were worried. 
Brong Ahafo topped in examination malpractices in 2014, according to a report released by the West African

Examinations Council (WAEC).... To reverse the trend, the directorate is collaborating with other relevant institutions, and has intensified invigilation in the ongoing WASSCE. (Ghanaweb, 2014, Malpractices-in-BA).

Again, according to the media report, "one out of every five candidates in the 2014 West Africa Senior School Certificate Examination (WASSCE) in the Brong Ahafo Region was involved in examination malpractices" (Ghanaweb, 2014, Malpractices-in-BA). BA ranked topmost in examination malpractices with over 4,000 cases. In as much as this is not a unique case in WASSEC, there is a growing concern among educationists and researchers (Jimoh, 2009; Onuka \& Durowoju, 2013). Basil Olatunbosun Jimoh (2009) was concerned about what is keeping students interested in cheating. Adams Onuka and Esther Durowoju (2013) attempted to set the concept of malpractices straight and redefine the agents and possible route of avoidance. However very little is investigating the moral domain or moral reasoning behind the students' act of abnormal behaviours in examination.

\subsection{Purpose and the Research Questions}

The present study is intended to investigate the moral reasoning behind secondary students cheating at examinations in selected secondary schools within one school district in Ghana, and by extension to study the development of these students' moral reasoning along the lines of Kohlberg's moral stages. The novelty of this study is the investigation of the variations in moral judgment arising as a result perceived judgment on a socio-moral dilemma in a normal school ecology where participants gain their own social knowledge and formulate moral judgments. There is an abundant literature to support the influence of school environment on moralization (Curren, 2014; Murphy, 2014; Strike, Haller \& Soltis, 1998; Starratt, 1990).

The question is simply:

- What are the levels of moral reasoning regarding examination malpractices among secondary school students at one district in the then Brong Ahafo region in Ghana?

- How do respondents' Simple sum scores (SSS) that is central to determining the moral reasoning levels aligned with their levels of confidence in examination looking at variations in attitudes towards seeking assistance during examination?

The significance of this study is however in deepening our understanding of the intuitive actions and sensitivity to moral dilemma caused by opportunities and the school environ. It is to establish evidence of moral reasoning abilities of our secondary schools to establish what is good and right thing to do in any situation or circumstances. Data on a sample of notorious cheating region should provide policy leadership and practical understanding of behaviours.

The study was conducted in one school district in the Brong Ahafo region of Ghana, a region which was notorious for examination malpractices but for their Metropolitan Education Director (MED) who introduced several interventions to minimize cheating at examinations in the 2017-2018 academic year group. The interventions are presumed to have resulted in no cancellation of examination results in the district this year (WASSCE results 2018).

\section{Review of Relevant Literature}

\subsection{Moral Domains}

Irrespective of debates in the theories, one thing is clear: moral development and moral reasoning literatures show an interdependence that nurtures character and ethical decisions (Beerthuizen, Brugman, \& Basinger, 2013; Gilligan, Ward, \& Taylor 1988; Passini, 2014; Rest, 1986). Marinus Beerthuizen and colleagues (2013) posterated juvenile or adolescence delinquency as propelled by between moral values and moral reasoning. Any act of defiance among young people is the result of the "overall level of justification of moral values/ decisions according to Kohlberg's stages of moral development" (pp. 460-461). The levels of judgment are classified as (i) Pre-conventional, (ii) Conventional, and (iii) PostConventional. Each of these levels have two stages making the Kohlberg's moralization stages six (Edwards, 2009). According to Alexander Edwards, Kohlberg's theory follows growing in moral orientations that are basically (a) normative order, (a) utility consequences, (c) justice or fairness, and (d) ideal self. The moral stages reflect Jean Piaget's theory of cognition, where children or adults "move through a sequence of stages in their moral reasoning" (Bjorklund \& Bee, 2008, p. 276) by constructing meaning out of interactions with any environment. Like Piaget is fond of saying "construction is superior to instruction" Mooney, 2000, p. 61). Hence evaluation of stages of moral reasoning can be based on Kohlberg's stages of moral development (see Table 1). 


\begin{tabular}{|c|c|c|c|}
\hline Levels & Stages Orientation & Reasoning & Social Perspective \\
\hline \multirow[t]{2}{*}{$\begin{array}{l}\text { Level I: Pre- } \\
\text { conventional }\end{array}$} & $\begin{array}{l}\text { Stage 1: Punishment and } \\
\text { obedience orientation } \\
\text { Or Heteronymous morality }\end{array}$ & $\begin{array}{c}\text { Avoidance of punishment, and } \\
\text { the superior power of } \\
\text { authorities }\end{array}$ & $\begin{array}{l}\text { Egocentric point of view: } \\
\text { Doesn't consider the } \\
\text { interests of others }\end{array}$ \\
\hline & $\begin{array}{l}\text { Stage 2: Naïve hedonism } \\
\text { orientation } \\
\text { Or Individualism, } \\
\text { instrumental purpose, and } \\
\text { exchange }\end{array}$ & $\begin{array}{l}\text { To serve personal needs or } \\
\text { interests in a world where you } \\
\text { have to recognize that other } \\
\text { people have their interests. }\end{array}$ & $\begin{array}{l}\text { Concrete individualistic } \\
\text { perspective: Right is } \\
\text { relative, conflicting, and } \\
\text { own interest }\end{array}$ \\
\hline \multirow[t]{2}{*}{$\begin{array}{c}\text { Level II: } \\
\text { Conventional }\end{array}$} & $\begin{array}{l}\text { Stage 3: Good-boy or Good- } \\
\text { girl orientation } \\
\\
\text { Or Mutual interpersonal } \\
\text { expectations, relationships, } \\
\text { and conformity }\end{array}$ & $\begin{array}{l}\text { The need to be good in your } \\
\text { own eyes and those of others. } \\
\text { Care for others nd how they } \\
\text { feel. Belief in the golden rule. } \\
\text { Support for rules and authority } \\
\text { which support stereotypical } \\
\text { good behaviour }\end{array}$ & $\begin{array}{c}\text { Perspective of the } \\
\text { individual in relationships } \\
\text { with other individuals. } \\
\text { Shared feelings, } \\
\text { agreements, expectations } \\
\text { take primacy over } \\
\text { individual interests }\end{array}$ \\
\hline & $\begin{array}{l}\text { Stage 4: Social order } \\
\text { maintaining orientation } \\
\text { Or Social systems and } \\
\text { conscience }\end{array}$ & $\begin{array}{l}\text { To keep the institution going as } \\
\text { a whole, avoidance of the } \\
\text { breakdown in the system, and } \\
\text { an imperative conscience to } \\
\text { defined obligations }\end{array}$ & $\begin{array}{l}\text { Differentiates societal point } \\
\text { of view from interpersonal } \\
\text { agreement or motives }\end{array}$ \\
\hline $\begin{array}{l}\text { Level III: Post- } \\
\text { conventional }\end{array}$ & $\begin{array}{l}\text { Stage 5: Social contract } \\
\text { orientation } \\
\text { Or utility and individual } \\
\text { rights }\end{array}$ & $\begin{array}{l}\text { A sense of obligation to law } \\
\text { because of one's social contract } \\
\text { to make and abide by laws for } \\
\text { the welfare of all and for the } \\
\text { protection of all people's right. } \\
\text { "The greatest good for the } \\
\text { greatest number" } \\
\text { The belief as a rational person } \\
\text { in the validity of universal } \\
\text { moral principles, and a sense of } \\
\text { personal commitment to them }\end{array}$ & $\begin{array}{c}\text { Prior-to-society } \\
\text { perspective. A rational } \\
\text { individual awareness of } \\
\text { values, rights, and social } \\
\text { attachments and contracts. } \\
\text { Considers moral and legal } \\
\text { points of view. } \\
\text { Perspective of a moral } \\
\text { point of view from which } \\
\text { social arrangements derive. } \\
\text { Individual recognizing the } \\
\text { nature of morality or the } \\
\text { fact that persons are ends } \\
\text { in themselves and must be } \\
\text { treated as such. } \\
\end{array}$ \\
\hline
\end{tabular}

Table 1: Contents of the Kohlbergian Moral Stages (Cited from Edwards, 2009)

Discussions on moral reasoning however must contain the concept of moralization both in context and dwell on universal values and expectations. A body of literature can be presented to illustrate the deficit of moralization and how these impact on development, judgment and decisions in life (Beerthuizen et al., 2013; Bee \& Bjorklund, 2004; Bjorklund \& Bee, 2008; Lovett \& Jordan, 2010; Noddings, 1984; Rachels \& Rachels, 2007; Shapiro \& Stefkovich, 2001). It was Ned Noodings (1984) who emphasized that the construction of ideal is based on one's exposure, constraints and attainability. Once a person can see a possibility of attaining results and pleasure, ethical or moral decisions attain high probability. Same can be deduced from the Utilitarianism principles by John Stuart Mill (1806-1873) regarding 'What's Right' and 'What's Wrong' - that people actions are directly related to happiness/ pleasure or the privation of pleasure or pain (Rachels \& Rachels, 2007b).

\subsection{Adolescence Morality and Cheating Behaviours}

Age is a very significant factor in determining the level of moral expectations. Society expects children to develop at a pace with stages of moral reasoning (Rest, 1986). Moralization theorists agree that age is a factor in developmental stages of any kind (Lovett \& Jordon, 2010). According to Benjamin Lovett and Alexander Jordan (2010), "many theories of moral development have focused on how children learn to distinguish moral from non-moral issues ... have investigated moral sensitivity, defined as the ability to recognise the presence of moral issues in real-world situations" (p. 175). To the researcher's moral sensitivity grows with age along two conceptions: normative and description, which in tend lead to different levels of moralization dependent on levels of preferences.

An adolescence stage of life is usually a transitional stage where most children reach puberty and it falls between that teens and legal age of adulthood (Bee \& Bjorklund, 2004). Helen Bee and Barbara Bjorklund (2004) call them young people yet to reach young adulthood. Other literature prefers to call them teenagers. Studies on adolescence tend to focus on "normative disturbances" (Steinbery \& Morris, 2001). Citing Bronfenbrenner's work in the late 1970s and 1980s, Laurence Steinberg and Amanda Morris (2001) contested the dominant studies focusing on adolescence behaviours influenced by "ecological perspective". Unfortunately, most researchers looked at adolescence as inherently problematic, full of stress, and identity crises. Erik Erikson's theory of adolescent identity (Valliant, 1998) sees teenager period as 
causes of childhood individualism verses socialization crisis, influenced by neighbourhood and peers who tend to be part of the ecological model by Bronfenbrenner (Brooks-Gunn, Duncan, \& Sealand, 1993; Steinberg \& Morris, 2001;). However, some studies have shown the positive influence of peer relationships for psychosocial development (Goldstein, DavisKean, \& Eccles, 2005). Peer influence can be positive or negative.

According to Sara Goldstein, Pamela Davis-Kean, and Jacquelynne Eccles,

"For adolescents, friends are providers of companionship, social and emotional support, and intimate selfdisclosure and reflection" (p. 402)

Notwithstanding, the researchers acknowledged the behavioural risks associated with peer relationships and peer influence. But they also support relationships that "have great potential to contribute to healthy psychosocial development ... [rather than] when adolescents' friends engage in problem behavior" (p. 402). Tamera Murdock, Natalie Hale and Mary JoWeber (2001) conducted a study purposely to attempt at predicting cheating behaviour. They discovered that at early adolescence academic pressure and social motivations were key predictors of possible cheating behaviour. The authors "hypothesized that students' academic self-efficacy and personal and classroom goal orientations would predict cheating" (p. 96). Therefore, in a situation where examination malpractices have become nuisance, especially at an adolescence stage where peer pressure, friendship, parental expectations and moral choices may be difficult to handle, the level of moralization is a significant factor in curbing cheating at examinations.

\section{Method}

\subsection{Participants}

The research design was descriptive survey to examine post-facto events. The sampling technique is that of twostage random sampling (Fraenkel \& Wallen, 2004, p. 103). First, three senior high secondary (SHS) schools were conveniently selected from the school district (i.e., they were labeled as School A, B, and C for anonymity). They happened to be two public SHSs and one private and in close proximity for easy access and characteristic similarities.

Next, a sample of 30\% of the total of 1251 candidates for the WASSCE 2017/2018 academic year using a proportion representation of the three selected schools and a randomly selected by ballot technique. Each examination candidate had an equal chance of being selected by picking YES from the ballot papers. Those who selected YES were given the option to further consent to their participation or stop at any time for ethical reasons. In all, the study sample size was 420 SHS students. Through the assistance of the Municipal Education Director (MED) parents were informed and the students were made to understand the purpose before volunteering to participate. School authorities, parents and students were also made to consent to participation because of the sensitivity of the subject matter.

Study participants (420 SHS WASSCE examination candidates) -with heterogeneous characteristics yet similar as they are adolescence, mixed-sexes students. Most of the students are in a boarding facility and few of them living approximately 20-25 kilometers radius from campuses. They were all taking the final West Africa Secondary School Certificate Examination (WASSCE) and may be supposedly going through the same emotional stress. The researcher sought the assistance of the MED, school administrators and individual gatekeepers to achieve $100.0 \%$ response rate with a significantly high number of the respondents giving usable data for quantitative analysis.

\subsection{Data Collection Instrument}

The instrument for data collection was researchers-designed with a guide from similar instrument used for measuring moral reasoning through moral scenarios for judgment (Loviscky, Trevino \& Jacobs, 2007). "Moral reasoning is the respondents' judgment based on cognitive socio-moral understanding and interpretation of professional or managerial moral dilemmas" (Edwards, 2009, p. 11). The instrument is fashioned on reviews of Loviscky et al.'s Managerial Moral Judgment test (MMJT) and Rest's Defining Issue Test (DIT-2), both have moral dilemmas as scenarios, "which comprise of a test of initial decisions, simple sum scores, and P-scores" (Edwards, 2009, p. 11).

The survey questionnaire therefore had two main sections: demographic and a moral scenario with the moral scenario divided into four sub-sections. Sub-section 1 is instructions and the short scenario: "Helping Josephine during examination"; sub-section 2 is one question item with three possible choices based on recommended moral action to be taken: "Should or Should not and a Neutral can't decide"; sub-section 3 has 12 question items that respondents are to rate their moral thinking based on a Likert scale of 1-5 ( $5=$ great, $1=$ none) which reflect pre-set moral development stages. An example of such items is: "Josephine was courageous to risk taking the Mathematics examination" after which students are asked to rate their moral perception or judgment on a scale of 1 to 5 . The last sub-section 4 is where respondents rank the 12 items according to their importance to him or her personally. This has four grades of importance: $1^{\text {st }}$ to $4^{\text {th }}$ importance in that order. Detail example was given for students to understand and make a decision/ choice.

During the survey administration the researchers explained clearly and participants had the chance to ask for further explanation before tackling the questionnaire. The entire exercise took about 30 minutes from distribution to collection among the seated students in an examination hall of the various selected three SHS campuses. A second data set came from the school administrators. Data on the final examination performance from each school was made available for analyses. (See Appendices B-D for details). For analysis the researcher was more interested in the WASSCE general core courses: i.e., English, Mathematics, Social Science and Integrated Science. These four subjects are compulsory for all candidates and a minimum grade of $\mathrm{D}$ or credit is required to get admission to any tertiary institution in Ghana. The rest of the subjects are electives and they were so many of such including languages. 


\section{Results Discussion}

\subsection{Demographic Results}

The respondents $(\mathrm{N}=420)$ provided minimal but significant variations in their demographic data. There were three secondary schools: School A (59.8\%), School B (23.3\%), and School C (16.9\%) respondents. Average age of respondents is 16.7 years who can be classified as adolescence or young adults (Bjorklund \& Bee, 2008). There were more girls (53.1\%) than boys (46.9\%). Majority of the students took general arts programme $(n=374,89.1 \%)$, followed by business (6.2\%) then science (4.5\%). The respondents can best be described as having homogeneous characteristics as SHS adolescence students except for their natural differences like gender and age.

\subsection{Research Questions}

Research question\#1: What are the levels of moral reasoning regarding cheating in an examination among these secondary school students at the then Brong Ahafo region in Ghana?

To answer this question, data from the moral scenario items were used. The results are discussed in three parts: Judgment 'should or should not' action, Simple Sum Scores (SSS), and the significant importance in ranking (P-values). First, Table 2 shows data from the first sub-section of the moral reasoning items: should or should not or can't decide was used.

\begin{tabular}{|c|c|c|}
\hline $\begin{array}{c}\text { What Should the Invigilator Do Regarding the Teacher Who Helped } \\
\text { Josephine during the Examination Because Josephine Was Sick? }\end{array}$ & $\mathbf{f}$ & $\mathbf{\%}$ \\
\hline Ask for what happened? & 242 & 57.6 \\
\hline Can't decide on this & 133 & 31.7 \\
\hline Should not take the matter seriously & 45 & 10.7 \\
\hline
\end{tabular}

Table 2: Respondents' Opinion on the Teacher Who Helped Josephine ( $\mathrm{N}=420)$

Table 2 shows majority (57.6\%) wanted authorities to take action but first probe into the matter before taking a decision. This is to do with perceived judgment and care processes. The students are exercising what comes naturally in moral reasoning - i.e., facts-finding. However, the rest (47.8\%) were either not sure or do not want any action taken against the teacher. This raises a question on the levels of moral reasoning of those respondents in terms of such a defining issue judgment (Rest, 1984). In fact, literature abounds to agree that there is always an element of personal judgment when it comes to situations (Flanagan \& Jackson, 1993; Kegan, 1986; Rest et al., 1999; Thoma, 2006). As students, their moral reasoning comes with many personal factors and human biases which should be evident in this case especially when it determines a person's (like their teacher's) fate. Many adolescences have the tendencies to save the face of their delightful peers or affectionate superiors (Bee \& Bjorklund, 2004).

Secondly, the statistical means for levels of moral reasoning are also determined by the Simple Sum Scores (SSS). SSS is calculated by a maximum of 60 scores (12x5 matrix) is achievable. For example, the item \#1: Josephine was courageous to risk taking the Mathematics examination ( $M e a n=36.65, \mathrm{SD}=7.48$ ) is for respondents to demonstrate a level moral care rather than moral justice for Josephine situation. Table 3 shows the results in details. Then from the 12 moral items the aggregate data shows the level of moral reason is considered moderate (Mean of Means $=2.98, \mathrm{SD}=1.51$ ), which is significant in suggesting normality that the students at this point were torn between the highest level moral reasoning (Postconventional, Means =5.0) and the lowest moral reasoning level (Preconventional, Means=1.0). At that mid-point an individual express either stage 3 or stage 4 , according to Kohlberg's stages. These are normal young adults at a conventional level where "mutual interpersonal expectations, relationships, and conformity" is the orientation (Bjorklund \& Bee, 2008, p. 277). Here the students play the 'good-boy' and 'good-girl' role to please authorities (Burr, 2014). Data confirms the findings of Rachel Burr's (2014) work among Vietnamese children who played by the rules to please authorities in the quest for "morality and goodness". Even though segregated data presented individuals as been able to score very high on the SSS (see Table 3), collectively the means scores show moderation.

Thirdly, the P-scores for respondents (Table 4) is that which help explain respondents perceived moral judgment based on what they considered important regarding their decisions (i.e., the 12 items) on the case of Josephine scenario. The results may not be strange since adolescence or young adults are prune to play along with the 'good-boy, good-girl' orientation even if their moralization levels show contrary. But here it tallies with their SSS and P-values that show Kohlbergian stages of 3 and 4 which is the belief in the golden rule, a mutual interpersonal expectations, relationships, and conformity orientation, sometimes is very much associated with conventional norms (Murdock et al., 2001).

Murdock et al. attempted to predict cheating behaviour and discovered that young people out of academic pressure and social motivations are susceptible to possible cheating behaviour depending on the students' academic self-efficacy and personal and classroom goal orientations (p. 96). However, for a moral reasoning they may conform to golden rules to avoid punishment from the adults. Therefore, in a situation where examination pressure is high adolescents are gullible and may change behaviour for any kind of support available especially in terms of supernatural nature. In a nutshell, the moral reasoning levels of the student respondents are comparatively moderate and normal for their development in respect to a void of opportunity pressure. 


\begin{tabular}{|c|c|c|c|c|c|c|c|c|c|c|c|c|}
\hline \multirow{2}{*}{$\begin{array}{c}\text { Moral Reasoning Question } \\
\text { items }\end{array}$} & \multirow[b]{2}{*}{ Mean } & \multirow[b]{2}{*}{ SD } & \multicolumn{2}{|c|}{ Great (5) } & \multirow{2}{*}{$\begin{array}{c}\text { Much } \\
\text { (4) } \\
\text { f }\end{array}$} & \multicolumn{3}{|c|}{ Somehow (3) } & \multicolumn{2}{|c|}{ Little (2) } & \multicolumn{2}{|c|}{ None (1) } \\
\hline & & & $\mathrm{f}$ & $\%$ & & $\%$ & $\mathrm{f}$ & $\%$ & $\mathrm{f}$ & $\%$ & $\mathrm{f}$ & $\%$ \\
\hline $\begin{array}{l}\text { 1. Josephine was courageous to } \\
\text { risk taking the Mathematics } \\
\text { examination }\end{array}$ & 3.78 & 1.41 & 206 & 49.0 & 43 & 10.2 & 95 & 22.6 & 26 & 6.2 & 50 & 11.9 \\
\hline $\begin{array}{l}\text { 2. She should not have } \\
\text { attempted taking the paper } \\
\text { on the floor, its cheating. }\end{array}$ & 3.38 & 1.49 & 150 & $35.7^{*}$ & 49 & 11.7 & 110 & 26.2 & $\begin{array}{c}17 \\
6\end{array}$ & 7.0 & 80 & 19.0 \\
\hline $\begin{array}{l}\text { 3. The student Mike should be } \\
\text { rewarded for helping } \\
\text { Josephine when sick }\end{array}$ & 2.71 & 1.52 & 77 & 18.3 & 62 & 14.8 & 92 & 21.9 & 39 & 9.3 & 150 & $35.7^{*}$ \\
\hline $\begin{array}{l}\text { 4. Such coding can itself be } \\
\text { dangerous if misinterpreted }\end{array}$ & 3.50 & 1.37 & 132 & $31.4^{*}$ & 96 & 22.9 & 96 & 22.9 & 40 & 9.5 & 56 & 13.3 \\
\hline $\begin{array}{l}\text { 5. It looks like Mike had already } \\
\text { discussed and planned the } \\
\text { coding and staging }\end{array}$ & 3.03 & 1.45 & 91 & 21.7 & 74 & 17.6 & 111 & $\begin{array}{c}26.4 \\
*\end{array}$ & 44 & 10.5 & 100 & 23.8 \\
\hline $\begin{array}{l}\text { 6. Is the motive for Josephine } \\
\text { getting sick quite obvious } \\
\text { that she needed help? }\end{array}$ & 2.85 & 1.44 & 76 & 18.1 & 65 & 15.5 & 111 & 26.4 & 56 & 13.3 & 112 & $36.7^{*}$ \\
\hline $\begin{array}{l}\text { 7. The invigilator should report } \\
\text { the suspicion and } \\
\text { recommend cancellation }\end{array}$ & 2,70 & 1.47 & 77 & 18.3 & 47 & 11.2 & 97 & 23.1 & 71 & 16.9 & 128 & $30.5^{*}$ \\
\hline $\begin{array}{l}\text { 8. Josephine is desperate and } \\
\text { has the right to cheat to reach } \\
\text { her goal in life? }\end{array}$ & 2.53 & 1.48 & 66 & 15.7 & 49 & 11.7 & 87 & 20.7 & 57 & 13.6 & 161 & $38.3^{*}$ \\
\hline $\begin{array}{l}\text { 9. Examinations are not fair and } \\
\text { students deserve better than } \\
\text { one day testing? }\end{array}$ & 3.17 & 1.52 & 117 & 27.9 & 77 & 18.3 & 98 & 23.3 & 28 & 6.7 & 104 & 24.8 \\
\hline $\begin{array}{c}\text { 10.Mike and the teachers are } \\
\text { heroes and Josephine have to } \\
\text { thank them well? }\end{array}$ & 3.07 & 1.53 & 105 & 25.0 & 77 & 18.3 & 91 & 21.7 & 36 & 8.6 & 111 & 26.4 \\
\hline $\begin{array}{c}\text { 11.Would you take such a risk in } \\
\text { order to pass mathematics } \\
\text { anytime? }\end{array}$ & 2.63 & 1.58 & 84 & 20.0 & 54 & 12.9 & 75 & 17.9 & 38 & 9.0 & 169 & $40.3^{*}$ \\
\hline $\begin{array}{l}\text { 12.The invigilator definitely saw } \\
\text { something but ignored } \\
\text { because it's a female }\end{array}$ & 2.31 & 1.41 & 54 & 12.9 & 26 & 6.2 & 101 & 24.0 & 54 & 12.9 & 185 & $44.0^{*}$ \\
\hline $\begin{array}{c}\text { Means of Means } \\
\text { (Aggregate Total) }\end{array}$ & 2.98 & 1.51 & & & & & & 6.6 & & 7.4 & & \\
\hline
\end{tabular}

Table 3: Respondents' Moral Reasoning Single Sum Scores

$(\mathrm{N}=420)$

*Bold Is For Emphasis on Highest or Significant Scores.
Key: $\quad 5=$ Great
$4=$ Much
$3=$ Somehow
$2=$ Little
$1=$ None 


\begin{tabular}{|c|c|c|c|c|c|c|c|c|c|}
\hline \multirow[t]{2}{*}{$\begin{array}{c}\text { Moral Reasoning Question } \\
\text { Items }\end{array}$} & \multirow[t]{2}{*}{$\begin{array}{l}\text { Kohlberg } \\
\text { Stage }\end{array}$} & \multicolumn{2}{|c|}{$\begin{array}{l}\text { 1st Important } \\
40 \text { Pts }\end{array}$} & \multicolumn{2}{|c|}{$\begin{array}{c}\text { 2nd Important } \\
30 \text { Pts }\end{array}$} & \multicolumn{2}{|c|}{$\begin{array}{l}\text { 3rd Important } \\
20 \text { Pts }\end{array}$} & \multicolumn{2}{|c|}{$\begin{array}{l}\text { 4th Important } \\
10 \text { Pts }\end{array}$} \\
\hline & & $f$ & Valid \% & $\mathrm{f}$ & Valid \% & $f$ & Valid \% & $f$ & Valid \% \\
\hline $\begin{array}{l}\text { Josephine was courageous to } \\
\text { risk taking the Mathematics } \\
\text { examination }\end{array}$ & Stage 4 & 164 & 39.0 & 44 & 10.5 & 52 & 12.4 & 48 & 11.4 \\
\hline $\begin{array}{l}\text { She should not have } \\
\text { attempted taking the paper } \\
\text { on the floor, its cheating. }\end{array}$ & Stage 3 & 31 & 7.4 & 135 & $32.1^{*}$ & 44 & 10.5 & 50 & 11.9 \\
\hline $\begin{array}{l}\text { The student Mike should be } \\
\text { rewarded for helping } \\
\text { Josephine when sick }\end{array}$ & $\mathrm{M}^{* *}$ & 57 & 13.6 & 56 & 13.3 & 115 & $27.4^{*}$ & 26 & 6.2 \\
\hline $\begin{array}{c}\text { Such coding can itself be } \\
\text { dangerous if misinterpreted }\end{array}$ & Stage 6 & 19 & 4.5 & 37 & 8.8 & 52 & 12.4 & 116 & $27.6^{*}$ \\
\hline $\begin{array}{l}\text { It looks like Mike had } \\
\text { already discussed and } \\
\text { planned the coding and } \\
\text { staging }\end{array}$ & Stage 4 & 32 & 7.6 & 32 & 7.6 & 27 & 6.4 & 29 & 6.9 \\
\hline $\begin{array}{l}\text { Is the motive for Josephine } \\
\text { getting sick quite obvious } \\
\text { that she needed help }\end{array}$ & Stage 2 & 8 & 1.9 & 24 & 5.7 & 29 & 6.9 & 21 & 5.0 \\
\hline $\begin{array}{l}\text { The invigilator should } \\
\text { report the suspicion and } \\
\text { recommend cancellation }\end{array}$ & Stage 4 & 43 & 10.2 & 22 & 5.2 & 26 & 6.2 & 15 & 3.6 \\
\hline $\begin{array}{l}\text { Josephine is desperate and } \\
\text { has the right to cheat to } \\
\text { reach her goal in life? }\end{array}$ & Stage 5 & 12 & 2.9 & 8 & 1.9 & 16 & 3.8 & 14 & 3.3 \\
\hline $\begin{array}{l}\text { Examinations are not fair } \\
\text { and students deserve better } \\
\text { than one day testing? }\end{array}$ & Stage 5 & 12 & 2.9 & 26 & 6.2 & 29 & 6.9 & 25 & 6.0 \\
\hline $\begin{array}{l}\text { Mike and the teachers are } \\
\text { heroes and Josephine have } \\
\text { to thank them well? }\end{array}$ & Stage 3 & 0.0 & 0.0 & 0.0 & 0.0 & 0.0 & 0.0 & 22 & 5.2 \\
\hline $\begin{array}{l}\text { Would you take such a risk } \\
\text { in order to pass } \\
\text { mathematics anytime? }\end{array}$ & Stage 3 & 18 & 4.3 & 12 & 2.9 & 9 & 2.1 & 24 & 5.7 \\
\hline $\begin{array}{c}\text { The invigilator definitely } \\
\text { saw something but ignored } \\
\text { because it's a female }\end{array}$ & Stage 5 & 24 & 5.7 & 23 & 5.5 & 21 & 5.0 & 30 & 7.1 \\
\hline
\end{tabular}

Table 4: Respondents' Ranking of Importance and Its Associated Kohlbergian Stages of Moral Reasoning P-Scores

$(\mathrm{N}=420)$

*Bold Is For Emphasis on Significant Scores That Correspondence with Kohlbergian Stages 5 \& 6 Qualifying For P-Scores (Post-Conventional) Depending on Ranking of Importance, Respondent Can Score a Total of 100 (I.E., $\left.1 \mathrm{st}=40,2^{\text {nd }}=30,3^{\text {rd }}=20,4^{\text {th }}=10\right) . * * M=$ Non-Score

Key: $40=$ Very Important $30=$ Important $20=$ Somehow Important $10=$ Little Important

To answer the research question 2; How do respondents' Simple sum scores (SSS) compare with Pre-Examination Confidence levels (PECL) when it comes to variations in attitudes towards seeking assistance during examination?

Simple sum scores (SSS) is central to determining respondents' moral reasoning levels. SSS alignment with their levels of confidence in examination may hypothetically affect attitudes towards seeking assistance during examination. We investigated the two variables by comparing the frequency analysis of the respondents' pre-examination confidence levels (PECL) (Table 5) and that of SSS scores (Table 3) to see if there is a significant variation in attitudes towards seeking assistance during examination. Data in Table 5 shows the PECL scores (i.e., Means $=1.84, \mathrm{SD}=66$ ) and Table 3 also shows the SSS Mean of Means scores (Mean =2.98, S=1.51). It is further compared with the frequencies of desiring choices of help respondent (Table 7). The hypothesis was accepted (i.e., SSS with Means=36.65, SD=7.46 is significantly aligned with (or almost equal in statistical weight) with PECL total with the Means $=3.67, \mathrm{SD}=31$. 


\begin{tabular}{|c|c|c|c|c|c|c|c|c|c|c|}
\hline What Grade Are You Expecting & \multicolumn{2}{|c|}{ A } & \multicolumn{2}{|c|}{ B } & \multicolumn{2}{|c|}{ C } & \multicolumn{2}{|c|}{ D } & \multicolumn{2}{c|}{ Means } \\
\cline { 2 - 12 } in the Following Subjects: & $\mathrm{f}$ & $\%$ & $\mathrm{f}$ & $\%$ & $\mathrm{f}$ & $\%$ & $\mathrm{f}$ & $\%$ & $\mathrm{M}$ & $\mathrm{SD}$ \\
\hline English Language & 94 & 22.4 & 253 & 60.4 & 72 & 17.2 & - & - & 1.95 & .63 \\
\hline Mathematics & 76 & 18.1 & 224 & 53.5 & 118 & 28.2 & 1 & .2 & 2.11 & .68 \\
\hline Integrated Science & 141 & 33.6 & 201 & 48.0 & 77 & 18.4 & 1 & .2 & 1.82 & .71 \\
\hline Social Studies & 252 & 60.0 & 140 & 33.3 & 26 & 6.2 & 2 & .5 & 1.46 & .61 \\
\hline
\end{tabular}

Table 5: Respondents' Pre-Examination Confidence Levels (PECL) by Subjects ( $N=420)$ Mean of Means $=1.84, \mathrm{SD}=66$

Key: Grade A =Excellent, B=Very Good, C=Good, D=Credit, F=Fail (No One Expected F)

Using the frequency data, Table 5 shows the confidence levels of the students for each core subject before taking their examinations. Data shows on average majority of the students anticipated moderate grades (grades B) in the various subjects including English (60.4\%), Mathematics (53.5\%), and Integrated Science (48.0\%). It is only in Social science that majority expected grade A (60.0\%). According to the results in Table 5, the pre-examination confidence levels were moderate (Mean of Means=1.84, SD=66), therefore with PECL high morale could be said to be moderately high, and cheating at the examination can be ruled out of the agenda if moral reasoning is significantly aligned.

When students were asked to show their eagerness to request for assistance just in case it was offered, Table 6 shows non-affirmative responses except for prayers (which connotes an intervention from a Supernatural entity). For example: Will you take the chance to get help? Majority answered NO (55.7\%). When asked: would you welcome any assistance from the following: teachers, WAEC invigilators, and external force through Prayers? Majority responded negatively; NO from teachers (59.5\%), NO from WAEC invigilators $(55.0 \%)$, yet help from the supernatural through prayers was significantly affirmative, YES (89.0\%).

\begin{tabular}{|c|c|c|c|c|c|c|c|c|}
\hline Answer Honestly About You Getting Help & \multicolumn{2}{|c|}{ Yes } & \multicolumn{2}{|c|}{ No } & \multicolumn{2}{c|}{ Not Sure } & \multicolumn{2}{c|}{ No response } \\
\hline & $\mathrm{f}$ & $\%$ & $\mathrm{f}$ & $\%$ & $\mathrm{f}$ & $\%$ & $\mathrm{f}$ & $\%$ \\
\hline Will you take the chance to get help? & 144 & 34.3 & 234 & 55.7 & 41 & 9.8 & 1 & .2 \\
\hline Your teachers were helpful? & 89 & 21.2 & 250 & 59.5 & 80 & 19.0 & 1 & .2 \\
\hline WAEC Representatives/ Invigilator & 106 & 25.2 & 231 & 55.0 & 82 & 19.5 & 1 & .2 \\
\hline Prayer before starting the exams & 374 & 89.0 & 41 & 9.8 & 4 & 1.0 & 1 & .2 \\
\hline
\end{tabular}

Table 6: Respondents' Opinion on Helpful Support during the Examination

$(\mathrm{N}=420)$

Hypothetically, comparing the scores from the PECL in both grades expectancy and asking for assistance Tables 5 and 6 it shows consistency in the respondents' moderation where by cheating is not expected. So, it could be stated that respondents' Simple sum scores (SSS) (Mean of Means $=2.98, \mathrm{SD}=1.51$ ) is also consistent with their confidence levels as indicated by the PECL (Mean of Means $=1.84, \mathrm{SD}=66$ ) all at moderate levels.

But them when a relationship between the PECL scores and SSS scores was computed to enhance our understanding of the respondents' moral reasoning it was negative $(r=.042)$. There is no significant correlation between the two variables $(p=396)$ therefore any comparison has to consider other extraneous factors such as opportunity to cheat and a cultivation of trust vs. mistrust which might play a significant influence in the variations of potential cheating behaviour based on individual rather than aggregate moral reasoning.

Based on data evidence the question of what respondents' Simple sum scores (SSS) may be significantly aligned with confidence levels of students, which accounts for variations in attitudes towards seeking assistance during examination is paradoxically sensitive and based on situational thinking and the circumstance leading to opportunity to cheat. The discussion can then continue with a question of trust among the respondents. It is all about trust in young adults when it comes to dealing with authorities (Bee \& Bjorklund, 2004).

Somehow when it comes to young people for the sake of fear and mistrust, which characterizes many adolescent or teenagers, majority would rather not risk placing their hope on the teachers, nor the WAEC invigilators especially. But it is evident that at that age many young people linger with mistrust in the establishment, and they show signs of fear of punishment and deception from adults or those in authorities therefore shows preference to value for sensitivity (Lovett \& Jordon, 2010; Rachels \& Rachels, 2007). At that point students have reached a higher sensitivity of preferences (Lovett \& Jordon, 2010) and are ready to choose what is right from wrong based on their own judgment and perceived risks (Rachels \& Rachels, 2007a, 2007b). But they exercise significant trust in the unknown, as in 'prayers' which is the expression of faith development and trust in the supernatural than people.

\section{Conclusion, Recommendations and Limitations}

\subsection{Conclusion}

The study is concluded on the fact that students are naturally focused on being good-boy and good-girls oriented when it comes to moral reasoning. The respondents who are considered are young adults (Bee \& Bjorklund, 2004) have developed normative judgment (conventional stages) based on their SSS scores, P-scores, and rating responses to a moral scenario. However, given the data it shows variations based on individual cognitive moral abilities and Kohlberg stages of 
moral development, ranging between Stages \#3 and \#4. However, none of the students is low in moral reasoning (Stages \#1 and \#2); neither have any one reached post-conventional (Stages \#5 and \#6), which is consistent with most literature on adult development (Bee \& Bjorklund, 2004; Bjorklund \& Bee, 2008; Steiberg \& Morris, 2001).

The researchers were interested in the different levels of moral reasoning, and how the respondents' simple sum scores (SSS) play when it comes to confidence levels before examination. This is significant because confidence can influence cheating or tendencies to cheat behaviours. Data shows a moderation in SSS mean scores and that of the postexamination confidence level (PECL). Both when compared SSS scores to PECL data it gives wrong assumptions and variances. The reality of moral reasoning computed using both frequencies and mean of means of all the items related negatively to PECL. Individuals may fall victim to cheating behaviour because of variances in PECL and opportunities.

It can therefore be concluded that the district secondary students are not ones that can be described as truant examination cheaters. Their behaviours may be susceptible to opportunity through teachers, corrupt WAEC agencies, and variances of moralization preferences which could be because of school environmental threats and other extraneous factors. The Brong Ahafo region may have been identified in the media as examination cheaters in the past (Ghanaweb, 2014). However, evidence shows a change in behaviour is possible due to appropriate interventions, such as the leadership exposure to prospective threats and understanding of the role levels of moral reasoning play in influencing cheating at examination.

\subsection{Recommendations}

The study recommends the following:

- First, moral reasoning levels are normal and development moderate but moral development content should be an integral part of the national curriculum at the all levels of education, particularly secondary level. This should be taken up by the GES curriculum and supervision unit to curb examination malpractices in the country. Content exposure to qualitative reasoning should engage students on knowledge in reasoning-ability, civility, and thinking and to develop a sense of responsibility towards the socio moral society.

- Second, educational leadership should formulate practical measures at GES secondary education unit to make cheating unattractive. Invigilators should consider examination candidates as venerable and susceptible to cheating. Invigilation should be vigilant, focused, and to perceive all SHS student as potentially capable of cheating. This should be the responsibilities of well-wishing school leaders, teachers, and WAEC as moral agents.

- Third, the consequences of examination cheating can be futile and life-wrecking. Pre-Examination Confidence Levels (PECL) should be monitored and built up. Motivational talks should be encouraged rather than fear and threats. This should be well emphasized and inculcated into the students' pre-examination moral reasoning sections through basic philosophical engagement, scenario-role play at schools, and a citizenship class/ or club and so forth. The kind of students we have these days are capable of understanding the consequences of their actions as 'good-boy' and 'good-girls' orientation seems to suggest as their moralization stages. However, situational leadership among schools may account for variances in reasoning.

- Forth, policy leadership should come from the Ministry of Education in Ghana to express 'zero' tolerance to cheating. The idea of punishments for offender should not be the way forward; avoidance should be the policy orientation. In other words, all loopholes should be blocked including teachers and WAEC agents who may be tempted to facilitate opportunities for these SHS students to cheat. Cheating undermines education results and should be 'zero' tolerated.

- Finally, well-wishing educators, WAEC researchers, and all stakeholders should be interested to advocate for moral reasoning assessments periodically, character education within the framework of moral development, and a good citizenship focused curricula activity as part of the national education agenda. Augmentation and extensive development of RME (religious and moral education) in Ghana should be examined critically in our National Education Agenda 2030 framework.

\section{Study Limitations}

The study encountered a few limitations worthy of discussion. First, the research design limits the discussions on quantitative method of moral judgment from adolescences. Quantitative methodology is limiting in matters of sensitivity, subjectivity, morality and personal judgment (Kohlberg, 1984). Particularly where the method happens to have no observable environment, humanistic expressions, and composure bodily. Secondly, the extent to which inferential analyses on one moral scenario limits extensive generalizability. More scenarios could add to significant conclusions. Thirdly, the opinions of the children in a focus group discussion, peer-to-peer exchanges, could have added extra dimension to the discourse. Next, there was an issue of Ghanaian socio-cultural context especially at the secondary level that is difficult to get reliable data and a real picture. The setting at which the questionnaire was administered was later realized by the researchers to have an imbedded issue that limits the investigation to students' 'quick-fixed' answering biases. In other words, respondents were getting ready for examination and may choose to be simple and non-analytical in answering questions on examination malpractices and their preferences in moralization (good-boy, good-girl orientation may challenge evidence)

Notwithstanding the study is a starting point in moral discourse. A further study may have to accommodate more moral dilemmas and a certain level of childhood spirituality. Childhood spirituality is not as intrusive as in other developed cultures. With the item on 'prayer' we noticed a significant affirmation (80.0\%) wanting to seek assistance from the supernatural, which shows the need for or interest in examining faith development in context. 


\section{References}

i. Adams O. U. Onuka, E. O. (2013). Stakeholders' role in curbing examination malpractice in Nigeria. International Journal of Economy, Management and Social Science, 2(6), 342-348.

ii. Bee, H. L., \& Bjorklund, B. R. (2004). The journey of adulthood. Upper Saddle River, NJ: Pearson/ Prentice Hall.

iii. Beerthuizen, M. G., Brugman, D., \& Basinger, K. S. (2013). Oppositional defiance, moral reasoning and moral value evaluation as predictors of self-reported juvenile delinquency. Journal of Moral Education, 42(4), 460-474.

iv. Bhana, D. (2014). Ruled by hetero-norms? Raising some moral quetions for teachers in South Africa. Journal of Moral Education, 43(3), 362-376.

v. Bjorklund, B., \& Bee, H. L. (2008). The journey of adulthood. Upper Saddle River, NJ: Pearson/ Prentice Hall.

vi. Brooks-Gunn, J., Duncan, G. J., Klebanov, P. K., \& Sealand, N. (1993). Do neighborhoods influence child and adolescent development? American Journal of Sociology, 99(2), 353-395.

vii. Carr, D. (2014). Metaphysics and methods in moral enquiry and education: Some old philosophical wine for new theoretical bottles. Journal of Moral Education, 43(4), 500-515.

viii. Chilver-Stainer, J., Gasser, L., \& Perrig-Chiello, P. (2014). Children's and adolescents' moral emotion attributions and judgements about exclusion of peers with hearing impairments. Journal of Moral Education, 43(3), 235-249.

ix. Curren, R. (2014). Motivational aspects of moral learning and progress. Journal of Moral Education, 43(4), 484499.

x. Edwards, A. K. (2009). Professional citizenship and otherness leadership: Examining the relationship between meaning in life, moral reasoning, and diversity amon graduate students. Doctoral dissertation. Bowling Green, Ohio: Bowling Green State University.

xi. Fraenkel, J. E., \& Wallen, N. E. (2006). How to design and evaluate research in education. New York, NY: McGraw-Hill.

xii. Ghanaweb. (2014, September 14th). Malpractices in Brong Ahafo region. Accra, Gh. Retrieved August 21st, 2018, from malpractices-in-B-A-353363)

xiii. GhanaWeb. (2017, August 10). 29 'Born again' Christians return their certificates to WAEC for cheating. Retrieved September 21, 2018, from https:// www.ghanaweb.com/ GhanaHomePage/ NewsArchive/ 29-bornagain-Christians-return-their-certificates-to-WAEC-for-cheating-568143

xiv. Ghanaweb. (2018, August 21). Article on cheating at examination. Accra, Ghana. Retrieved from from https:/ / www.ghanaweb.com/ GhanaHomePage/ NewsArchive/ WASSCE-1-873-private-candidates-resultswithheld-for-alleged-cheating-603490)

xv. Gilligan, C., Ward, J. V., Taylor, J. M., \& Bardige, B. (1988). Mapping the moral domain. Cambridge, MA: Harvard University Press.

xvi. Goldstein, S. E., Davis-Kean, P. E., \& Eccles, J. S. (2005). Parents, Peers, and Problem Behavior: A Longitudinal Investigation of the Impact of Relationship Perceptions and Characteristics on the Development of Adolescent Problem Behavior. Developmental Psychology, 41(2), 401-413.

xvii. Jimoh, B. O. (2009). Examination malpractice in secondary schools in Nigeria: What sustains it? European Journal of Educational Studies, 1(3), 101-108.

xviii. Kohlberg, L. (1984). The psychology of moral development: The nature and validity of moral stages. San Francisco, CA: Harper \& Row.

xix. Lovett, B. J., \& Jordon, A. H. (2010). Levels of moralisation: A new conception of moral sensitivity. Journal of Moral Education, 39(2), 175-189.

xx. Lozada, M., D'Adamo, P., \& Carro, N. (2014). Plasticity of altruistic behavior in children. Journal of Moral Education, 43(1), 75-88.

xxi. Mooney, C. G. (2000). Theories of childhood: An introduction to Dewey, Erkson, Piaget \& Vygotsky. St Paul, MN: Redleaf Press.

xxii. Murphy, P. (2014). Teaching applied ethics to the righteous mind. Journal of Moral Education, 43(4), 413-428.

xxiii. Nooddings, N. (1984). Caring: A feminine approach to ethics and moral education. Berkeley, LA: University of California Press.

xxiv. Passini, S. (2014). The effect of personal orientations toward intergroup relations on moral reasoning. Journal of Moral Education, 43(1), 89-103.

xxv. Passini, S. (2014). The effect of personal orientations toward intergroup relations on moral reasoning. Journal of Moral Education, 43(1), 89-103.

xxvi. Rachels, J., \& Rachels, S. (2007a). The elements of moral philosophy. Boston, MA: McGraw Hill.

xxvii. Rachels, J., \& Rachels, S. (2007b). The right thing to do: Basic readings in moral philosophy. Boston, MA: McGraw Hill.

xxviii. Rest,J. R. (1986). Moral development: Advances in research and theory. New York, NY: Praeger Publishers.

xxix. Shapiro, J. P., \& Stefkovich, J. A. (2001). Ethical leadership and decision making in education: Applying theoretical perspectives to complex dilemmas. Mahwah, NJ: Lawrence Erlbaum Associates.

xxx. Steiberg, L., \& Morris, A. S. (2001). Adolescence development. Annual Review Psychology, 2001(52), 83-110.

xxxi. Starratt,R. J. (1994). Building an ethical school: A practical response to the moral crisis in schools. London, Uk: The Falmer Press.

xxxii. Starratt, R. J. (1990). The drama of schooling / The schooling drama. London, Uk: The Falmer Press.

xxxiii. Strike, K. A., Haller, E. J., \& Soltis, J. F. (1998). The ethics of school administration (2nd ed.). New York: Teachers 
College Press, Columbia University.

xxxiv. Vaillant, G. E. (1993). The wisdom of the ego. Cambridge, MA: Harvard University Press.

xxxv. WASSCE Results. (2018, July 22). West African Examination Council examination reults are out. Retrieved February 5th, 2019, from waec: https:/ / www.waec.com/ wassce-examination-results-2018/ report 